\title{
Influence of Weir Construction on Chemical Water Quality, Physical Habitat, and Biological Integrity of Fish in the Geum River, South Korea
}

\author{
Sang-Jae Lee ${ }^{1,2}$, Kwang-Guk An ${ }^{1 *}$ \\ 'Department of Biological Science, College of Biological Sciences and Biotechnology, \\ Chungnam National University, Daejeon 34134, Republic of Korea \\ ${ }^{2}$ Iksan Chemical Emergency Management Center, Iksan 54526, Republic of Korea
}

Received: 8 March 2018

Accepted: 29 May 2018

\begin{abstract}
The objectives of this study were to determine the long-term changes in water chemistry, physical habitat, and fish fauna/composition before and after construction of the Sejong Weir in Geum River, South Korea, during 2007-2014, and to evaluate the integrated ecological health based on chemical water quality, physical habitat, and biotic integrity using a star plot integration approach. As an indicator of water quality, the mean total phosphorus (TP) in the surface water decreased 2.6-fold after weir construction, indicative of $\mathrm{P}$ sedimentation from the water column due to structural changes from a lotic to a lentic system. The chlorophyll-a concentration decreased in response to P levels. Considering total nitrogen $(\mathrm{TN})$, more than $91.7 \%$ of the total observations after weir construction $(\mathrm{n}=96)$ had a TN:TP ratio $>17$, indicating potential P limitations on algal growth. The log-transformed TN:TP ratio had a weak positive correlation $\left(p<0.005, \mathrm{R}^{2}=0.085, \mathrm{n}=96\right)$ with $\mathrm{TN}$ and a strong negative correlation $\left(p<0.001, \mathrm{R}^{2}=0.575, \mathrm{n}=96\right)$ with TP. This indicated that the N:P ratio was regulated mainly by variations in $\mathrm{P}$ rather than N. After weir construction, the population of the lotic-type fish Zacco platypus decreased 13-fold, and the population of the lentic-type fish Pseudorasbora parva increased 3-fold. Overall, the integrated ecological health assessments revealed large degradations of $>3$-fold in biotic health, 2 -fold in physical habitat health, and $>5$-fold in chemical health after weir construction.
\end{abstract}

Keywords: biological integrity, fish fauna, integrated ecological health, nutrients, weir construction

\section{Introduction}

In recent years, weirs and artificial dams have been built continuously in both small streams and large rivers in order to secure agricultural irrigation and drinking

*e-mail: kgan@cnu.ac.kr water in watersheds throughout Korea [1]. Due to the monsoon climate, the distribution of rainfall is not consistent among seasons, and securing water resources through multipurpose construction of large dams in Korea is considered to be indispensable [2]. The "Four Major River" project, originally known as the Korean New Deal project, was created in 2008 to resolve water problems such as uneven supply and demand of water 
resources, floods, and droughts [3]. Three weirs, the Sejong, Kongju, and Beakjae, were installed in the Geum River watershed. The goal of the project was to provide fundamental measures to protect against flood damage and drought caused by global warming and to expand investments in social overhead capital. It has since been adopted as a national project for ecosystems with the greatest hydrological and ecological alterations [4].

Despite the original intent, numerous studies have found that weir construction results in the degradation of chemical water quality such as nutrient enrichment [5], habitat disturbance from lotic (river-like) to lentic (lake-like) systems [6], and biological problems such as massive fish kills [7] and toxic algal blooms [8]. For example, phosphorus (P) and nitrogen (N) accumulations in the sediment of weirs in the Geum River have accelerated eutrophication. Moreover, oxygen depletion in the deep zone and phytoplankton algal blooms have occurred continually in lentic-like systems [9]. In addition, chemical water quality pollution has emerged as a major environmental problem for local communities. Under the current conditions, the river bed structure and functions have been affected by habitat simplification and hypoxia at the bottom of the system [10]. At the Sejong Weir, biological health has degraded rapidly due to the dominance of exotic species [11], habitat simplification due to silt accumulation [12], and increased frequency of fish kills.

Such modifications to the physical habitat and hydrological dynamics change the structure of fish species and trophic relationships in river ecosystems, resulting in deterioration of its ecological health. Weir construction has been reported to have various impacts on the chemical conditions [13] and food chains [14] of aquatic ecosystems, and the key impacts are explained well by the serial discontinuity concept of Ward and Stanford [15]. This concept states that artificial weir and dam construction results in discontinuous ecological characteristics upstream, midstream, and downstream in the river ecosystem, thereby influencing ecological structures and functions.

Weir construction causes changes in channel structure and river morphology [16]. Such physical modifications result in an increase in water retention time, and the types of fish may change due to a shift from a lotic to lentic habitat [17]. In turn, these physical environmental changes simplify the fish habitat, which eventually becomes an environment in which only a few fish species can survive by adapting to the changing environment [18]. In addition, weirs interfere with the mobility of living organisms, such as migratory fish [19].

Meanwhile, weir construction can cause the accumulation of sediments and pollutants in the water body, increasing nutrient levels (e.g., $\mathrm{P}$ and $\mathrm{N}$ ) and accelerating eutrophication [20], which can lead to a dramatic increase in the productivity and composition of primary producers in the modified system [21] and a decrease in dissolved oxygen (DO) in the hypolimnion. In the Baekjae Weir of the Geum River, such changes have triggered massive fish kills [22]. Since increased water levels and frequent water level fluctuations from weir gate control damage riparian vegetation, fish spawning grounds and shelters may be altered.

The objectives of this study were to determine the long-term changes in water chemistry, physical habitat, and fish fauna/composition before and after weir construction and to perform an integrative health assessment based on the chemical water quality, physical habitat, and biotic integrity of the Geum River at the Sejong Weir. The physical habitat health conditions were determined using a qualitative habitat evaluation index, and chemical health was evaluated using water chemistry parameters. In addition, we determined the biological health based on the index of the biological integrity (IBI) model and analyzed the relationships among trophic level, tolerance guild, and fish habitat guild. Based on these parameters, the integrative ecological health was compared before and after weir construction using a star plot integration approach.

\section{Materials and Methods}

\section{Study Watershed and Sampling Sites}

The Geum River watershed has an area of $9,912 \mathrm{~km}^{2}$, and the river spans $394 \mathrm{~km}$ from the headwater to the estuary (Fig. 1). The river watershed includes several large tributaries of Miho Stream, Gap Stream, Bocheong Stream, and the Cho River. It is influenced substantially by many nonpoint (e.g., rice paddies) and point (e.g., wastewater disposal plants and sewage treatment plants) sources of pollution. Three artificial weirs were constructed in the downstream region of the river under a government project in 2012. The present study was conducted at the Sejong Weir, the most upstream of the three weirs, and this weir is 4 $\mathrm{m}$ tall and $348 \mathrm{~m}$ wide with a water storage capacity of 1.3 million tons.

\section{Fish Sampling}

Fish assemblages were collected twice at each sampling site from 2007 to 2014 during the premonsoon and post-monsoon seasons. We selected these two seasons due to the high hydrological stability and lack of flooding. Fish sampling was performed based on the catch per unit effort wading method [23] in all habitat types (e.g., riffles, runs, and pools). The distance and time elapsed for sampling were at least $100 \mathrm{~m}$ and $60 \mathrm{~min}$, respectively. A casting net (mesh size: $7 \times 7$ $\mathrm{mm}$ ) and kick net (mesh size: $4 \times 4 \mathrm{~mm}$ ) were used for sampling, as they are the most popular fish sampling 


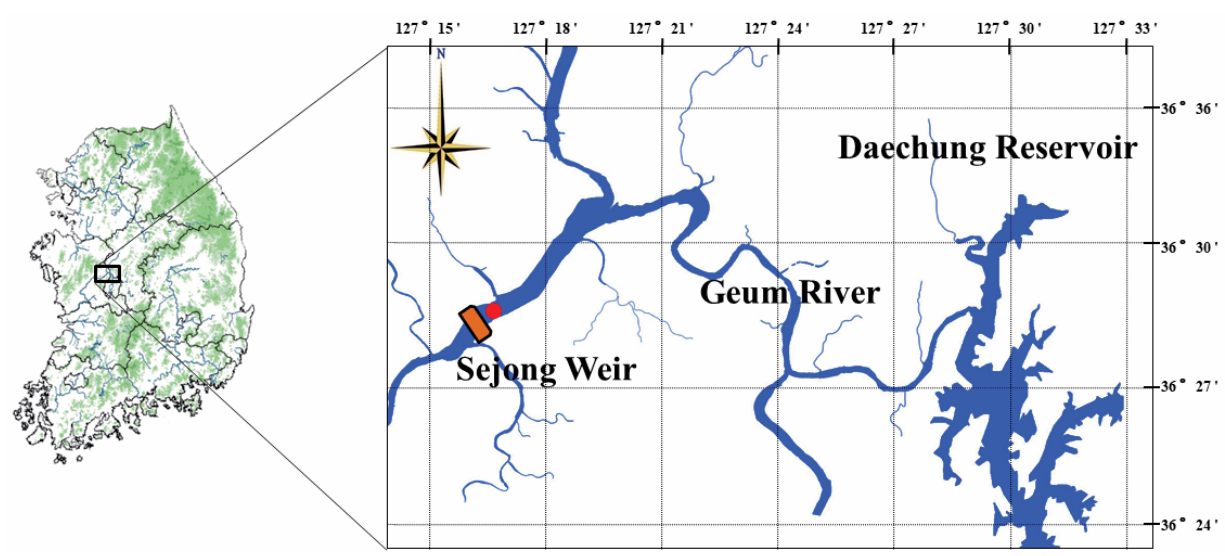

Fig. 1. Map of the study site at Sejong Weir.

gear used in Korea. All fish were identified in the field and released immediately. The external characteristics of individual fish were examined in the laboratory for deformities, erosions (e.g., on skin and barbels), lesions (e.g., open sores and ulcerations), and tumors. Tolerance and trophic guild analyses were based on regional studies [24, 25].

\section{Multimetric Fish IBI Model}

The biological health of the lotic ecosystem was evaluated using a multimetric fish IBI model. The metrics consisted of three major ecological characteristics: species richness according to the stream order (M1, M2, and M7), trophic and tolerance guild composition (M3-M6), and fish abundance according to health condition (M8). The metrics were defined as follows: M1, total number of native species; M2, number of riffle benthic species; M3, number of sensitive species; M4, proportion of tolerant species; M5, proportion of omnivorous species; M6, proportion of native insectivorous species; M7, total number of native individuals; and M8, proportion of abnormal individuals. Each metric was assigned a score of 1, 3, or 5, and five classification criteria were used: excellent $(A ;$ score $=40-36)$, good $(B ; 34-28)$, fair $(C ; 26-20)$, poor $(\mathrm{D} ; 18-14)$, and very poor $(\mathrm{E} ; \leq 13)$. Detailed descriptions of the specific metric characteristics and scoring criteria for the model are available.

\section{Reference Stream Analysis}

For the integrated health assessment, a reference site was selected at the Muju Namdae Stream in the Geum River watershed, which is located in the central region of the Korean Peninsula and experiences a temperate climate. The reference site is a fourthorder stream located near Seomyeon Bridge that is predominantly surrounded by forest $(>70 \%)$ and has a moderately well-developed riffle-pool morphology with gravel as the dominant substratum. According to the United States Environmental Protection Agency
[26] and Barbour et al. [27], a reference stream should be located in the same watershed as the surveyed stream, and reference conditions are best established through systematic monitoring of sites that represent the natural range of variation under minimally disturbed water chemistry, habitat, and biological conditions [28]. The reference site was affected by leastpoint and non-point sources within the Geum River watershed.

\section{Chemical Analysis}

Chemical water quality was analyzed using long-term data from the sampling site obtained from the Ministry of the Environment of Korea, and water quality impacts were analyzed based on three categories: before $\left(B_{w c}, 2007-2008\right)$, during $\left(U_{w c}, 2009-2011\right)$, and after weir construction $\left(\mathrm{A}_{\mathrm{wc}}, 2012-2014\right)$. Surface water sampling at the study site was conducted monthly during 2007-2014, and $\mathrm{pH}$, DO, biological oxygen demand (BOD), suspended solids (SS), electrical conductivity (EC), and chlorophyll-a (Chl-a) were analyzed. Various nutrients, such as total N (TN), dissolved $\mathrm{TN}$, ammonia $\mathrm{N}$, total $\mathrm{P}(\mathrm{TP})$, dissolved total P (DTP), and phosphate $\mathrm{P}$, were analyzed following the Korean Standard Chemical Analytical Methods.

\section{Empirical Models}

To analyze the relationships between $\mathrm{N}$ and $\mathrm{P}$ concentrations and sestonic Chl-a, as a measure of algal productivity we developed empirical models of TP-Chl-a, TP-TN:TP, and TN-TN:TP. For temporal analysis, water quality data were categorized into three seasons (pre-monsoon, monsoon, and post-monsoon) and $\log _{10}$-transformed to create a normal distribution curve. Then we performed Pearson's correlation analysis and regression analysis. All statistical analyses were conducted to assess the differences between $\mathrm{B}_{\mathrm{wc}}$ and $\mathrm{A}_{\mathrm{wc}}$ using SPSS ver. 12.0 for Windows. 


\section{Analysis of the Integrated Health Assessment Model}

The integrated health assessment model was developed using a multimetric approach to ecological health. The model was composed of multiple functional metrics and was based on the integration of all parameters derived from biological, chemical, and physical habitat health parameters. The values of the integrated health assessment model were calculated using the star plot approach.

We included six metrics for the biological health assessment: total number of native fish species (BM1), number of riffle benthic species (BM2), proportion of tolerant individuals (BM3), proportion of omnivorous individuals (BM4), total number of native individuals (BM5), and proportion of individuals with deformities, erosions, lesions, or tumors (BM6). In addition, we considered six physical habitat health metrics: epifaunal substrate/available cover (PM1), embeddedness (PM2), velocity/depth combination (PM3), sediment deposition (PM4), channel alteration (PM5), and frequency of riffles or bends (PM6). Finally, we considered six chemical parameter metrics: BOD (CM1), total SS (CM2), TN (CM3), TP (CM4), EC (CM5), and Chl-a (CM6). The integrated model values were expressed as the sum of each area based on a star plot representing the integrated ecological health value. The area score enclosed by each star plot was used to compare the values of the reference site relative to their ecological health response to environmental conditions. The area score of the star plot was calculated using the approach described by Beliaeff and Burgeot [29] and Kim et al. [30]

\section{Statistical Analysis}

All data were statistically analyzed by discriminant function analysis, regression analysis, and Pearson's correlation analysis using the SPSS statistical package ver. 12.0 for Windows.

\section{Results and Discussion}

\section{Water Chemistry and Relationship with Fish Composition}

The N:P ratio, DTP, phosphate $\mathrm{P}$, and $\mathrm{SS}$ in ambient water were determined and compared among the dominant fish species (Table 1). Zacco platypus, a dominant species in Korean watersheds [31], preferred a low $\mathrm{N}: \mathrm{P}$ ratio $(\leq 25)$, and the relative abundance of the fish was $37.5 \%$ under such conditions. In contrast, under an $\mathrm{N}: \mathrm{P}$ ratio $>25$, the $Z$. platypus population accounted for only $14.3 \%$ of all fish. The relative abundance of Pseudogobio esocinus, which is an intermediate species in terms of tolerance and insectivore species, was $42.9 \%$ under an N:P ratio of 24.5.

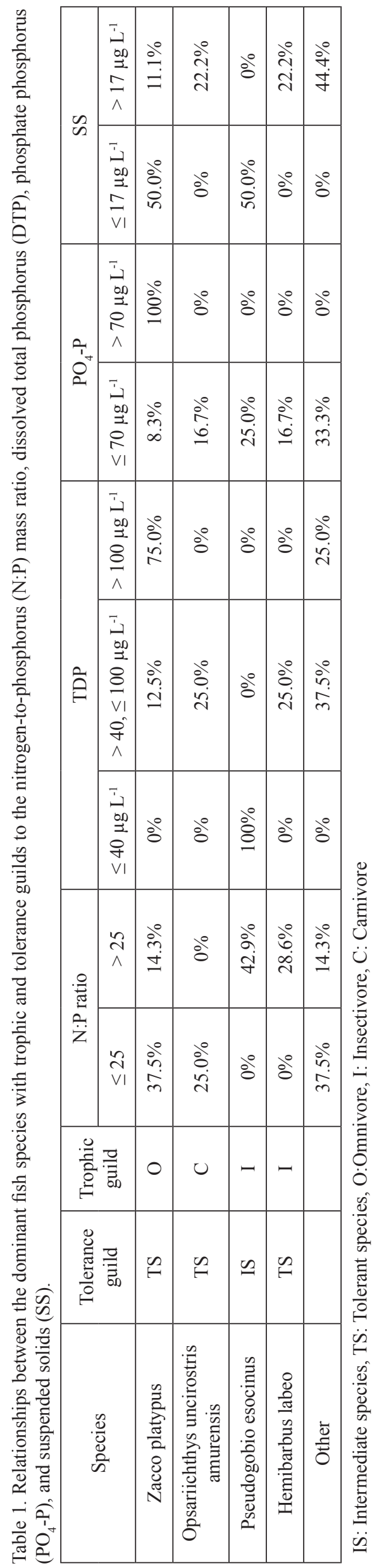




\section{Compositional Changes in Fish Species}

During the study, we collected 9 families and 23 species at the sampling site. Z. platypus, a typical lotic-type fish, dominated the community, with a relative abundance of $28.4 \% \mathrm{~B}_{\mathrm{wc}}$, which decreased by $35 \% \mathrm{~A}_{\mathrm{wc}}$. The rapid decline in Z. platypus was caused by the combined impacts of the disappearance of riffles, sediment dredging, and channelization for the weir construction, as the system changed rapidly from a lotic to a lentic system [32]. The Z. platypus population decreased from 375 individuals $B_{w c}$ to 29 individuals $A_{w c}$. In contrast, the population of the lentic-type fish Pseudorasbora parva increased from 5 (range: 4-5) individuals $\mathrm{B}_{\mathrm{wc}}$ to 16 (range: 0-30) individuals $\mathrm{A}_{\mathrm{wc}}$, and the relative abundance of Carassius auratus, a typical lentic-type fish, increased from 1.4 (range: 0-3.6)\% $\mathrm{B}_{\mathrm{wc}}$ to 5.1 (range: $\left.0-10.4\right) \% \mathrm{~A}_{\mathrm{wc}}$. Similar changes were observed for Cyprinus carpio, a lentic species (Fig. 2). During the $\mathrm{A}_{\mathrm{wc}}$ period, marked increases in lentic species and decreases in lotic species were apparent. This indicated that the simplification of trophic singularity due to the dominance of omnivorous and lentic-type fishes disturbed the ecosystem [33], as measured using the ecosystem health index [34] and fish compositional changes.

\section{Compositional Modifications of Exotic and Endemic Species}

A previous study conducted in the Geum indicated that no exotic species were present before the 1990s [35]. By contrast, exotic species were collected in this study, including Carassius cuvieri, Lepomis macrochirus, and Micropterus salmoides. The relative abundance of exotic species at the Sejong Weir was $0 \% \mathrm{~B}_{\mathrm{wc}}$; however,
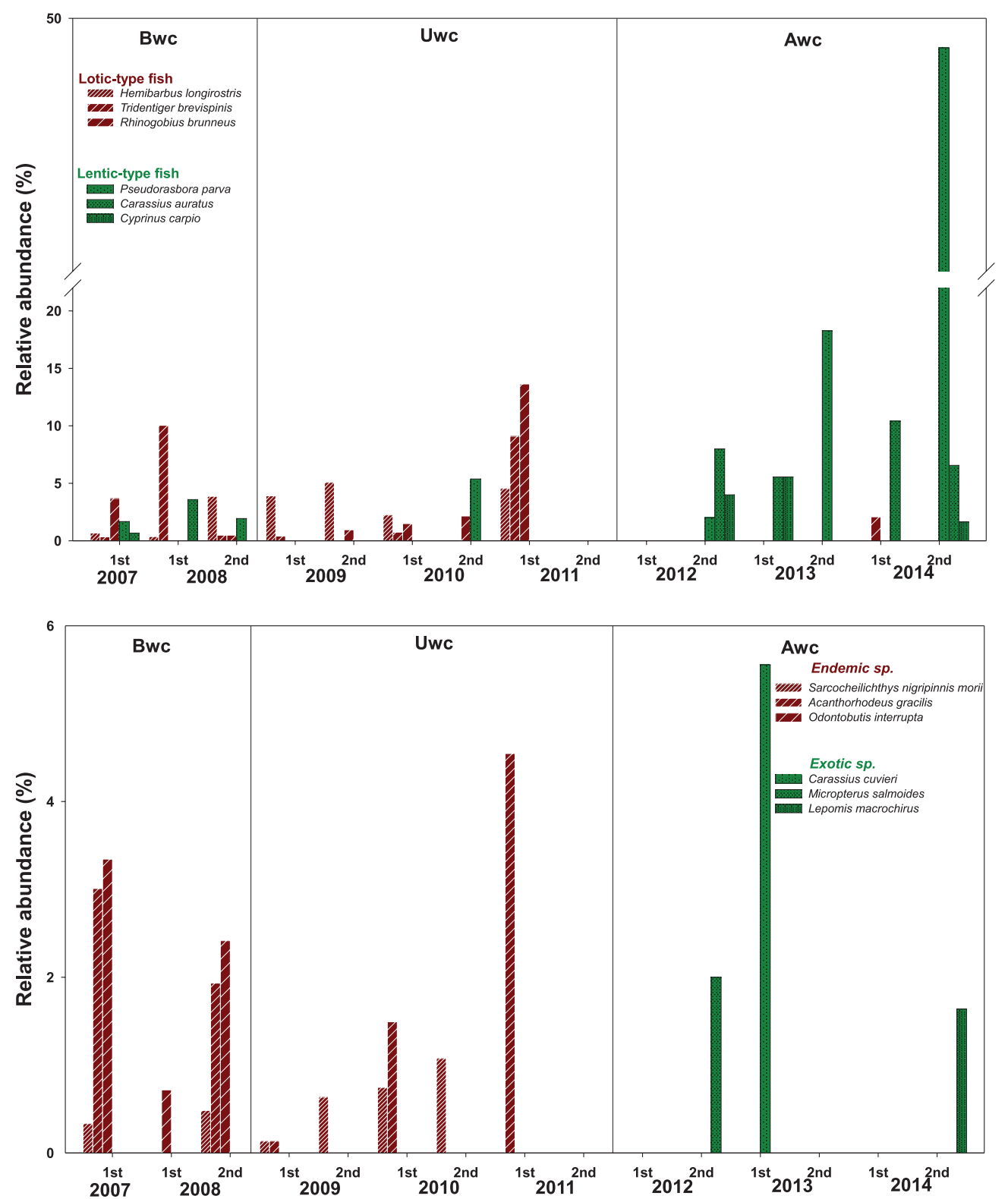

Fig. 2. Interannual fluctuations in the relative abundance of lotic-type versus lentic-type fish, and endemic versus exotic species. 
Table 2. Biological health assessment using a multimetric fish model of the index of biological integrity before $\left(B_{w c}\right)$, during $\left(U_{w c}\right)$, and after $\left(\mathrm{A}_{\mathrm{wc}}\right)$ weir construction.

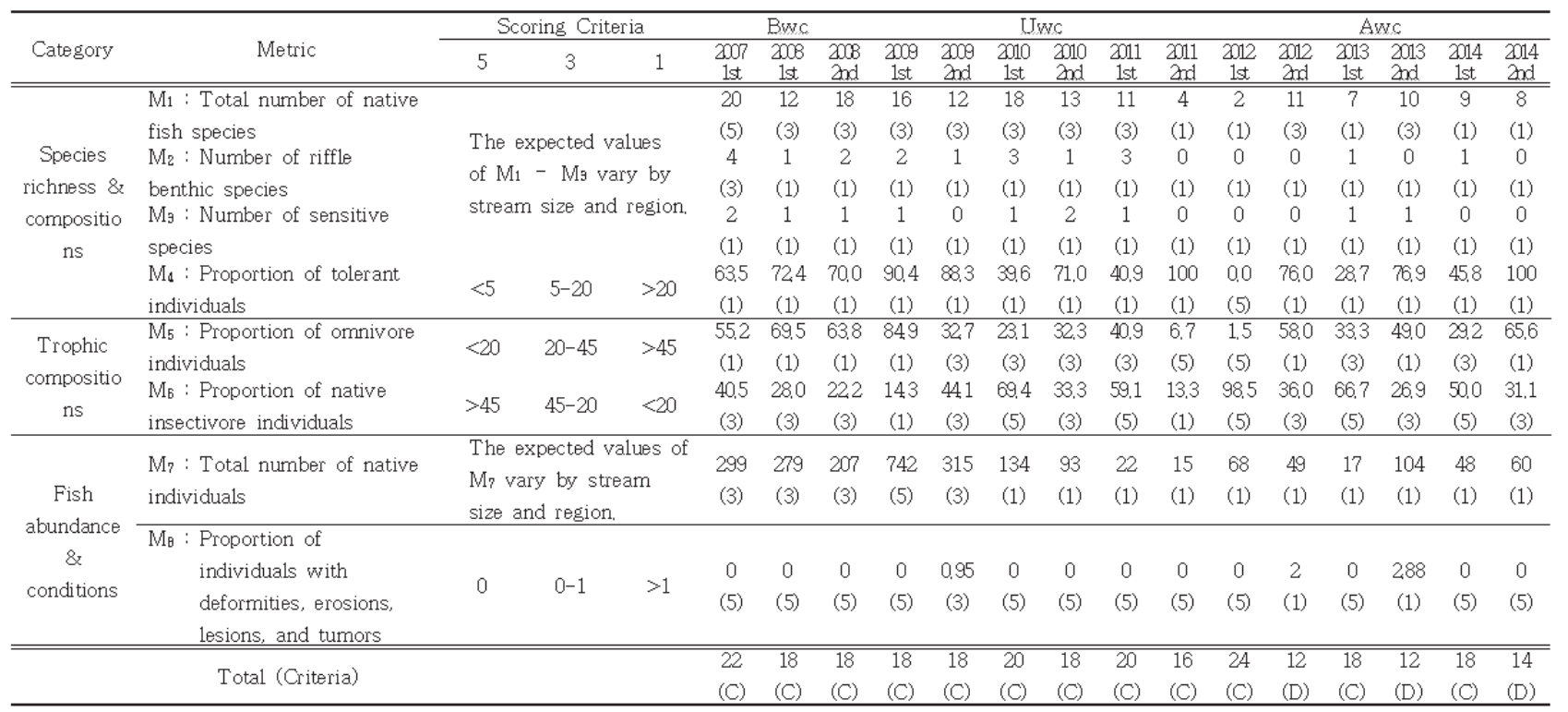
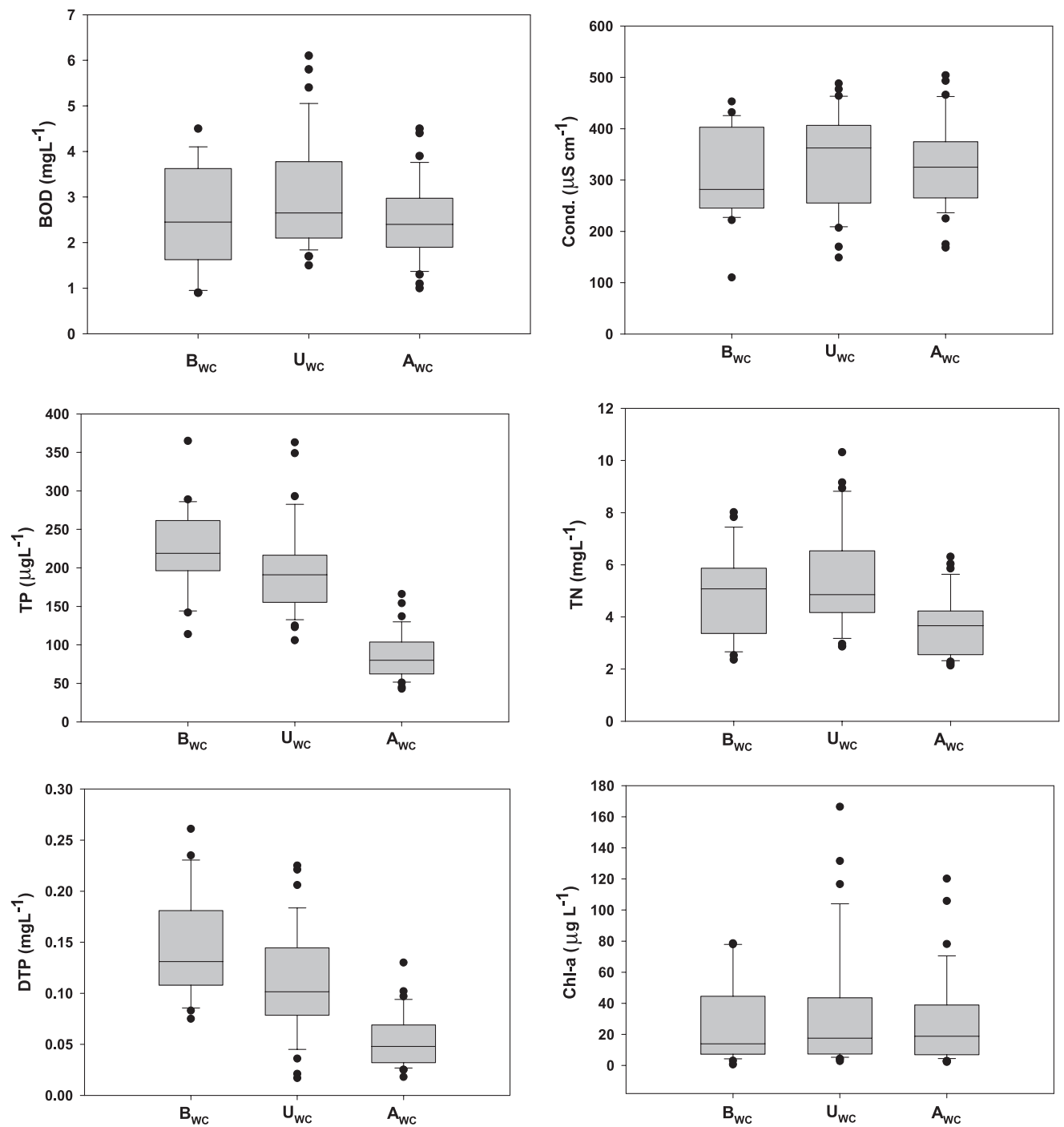

Fig. 3. Biological oxygen demand (BOD), electrical conductivity (Cond.), total phosphorus (TP), total nitrogen (TN), dissolved total phosphorus (DTP), and chlorophyll-a (Chl-a) before $\left(\mathrm{B}_{\mathrm{wc}}\right)$, during $\left(\mathrm{U}_{\mathrm{wc}}\right)$, and after $\left(\mathrm{A}_{\mathrm{wc}}\right)$ weir construction. 
the relative abundances of $L$. macrochirus, $M$. salmoides, and $C$. cuvieri were $1.6 \%, 2.0 \%$, and $5.6 \%$, respectively, $\mathrm{A}_{\mathrm{wc}}$. According to a previous study, the exotic species distribution in the river cannot be directly explained by water chemistry alone, and other environmental factors should be considered [36]. Therefore, we consider the cause of the increase in exotic species at the Sejong Weir to be a combination of water residence time and water quality deterioration [37, 38].

$\mathrm{B}_{\mathrm{wc}}$, we collected nine endemic species (e.g., Acanthorhodeus gracilis, Odontobutis interrupta, and Pseudobagrus koreanus). However, only five species were collected $\mathrm{A}_{\mathrm{wc}}$. The relative abundance of Sarcocheilichthys nigripinnis decreased from $7.4 \% \mathrm{~B}_{\mathrm{wc}}$ to $2.8 \% \mathrm{~A}_{\mathrm{wc}}$, that of $A$. gracilis decreased from $1.6 \%$ $\mathrm{B}_{\mathrm{wc}}$ to $0 \% \mathrm{~A}_{\mathrm{wc}}$, and that of $O$. interrupta decreased from $2.2 \% \mathrm{~B}_{\mathrm{wc}}$ to $0 \% \mathrm{~A}_{\mathrm{wc}}$. According to the Red Data Book of Endangered Fishes published by the International Union for the Conservation of Nature, S. nigripinnis and Squalidus gracilis were categorized as "near threatened" and "of least concern," respectively; however, they were not found during the $\mathrm{A}_{\mathrm{wc}}$ period.

\section{Results of the IBI Analysis}

The IBI values at the Sejong Weir ranged from 12 to 24 in the watershed, depending on the sampling period, averaging $17.7(\mathrm{n}=15)$ during the study (Table 2$)$, and

a)

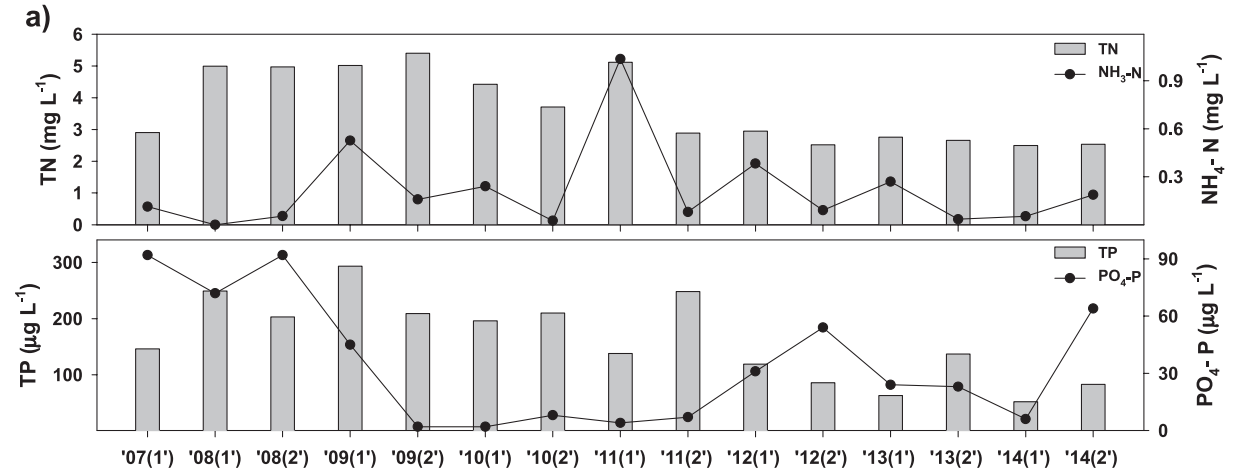

b)

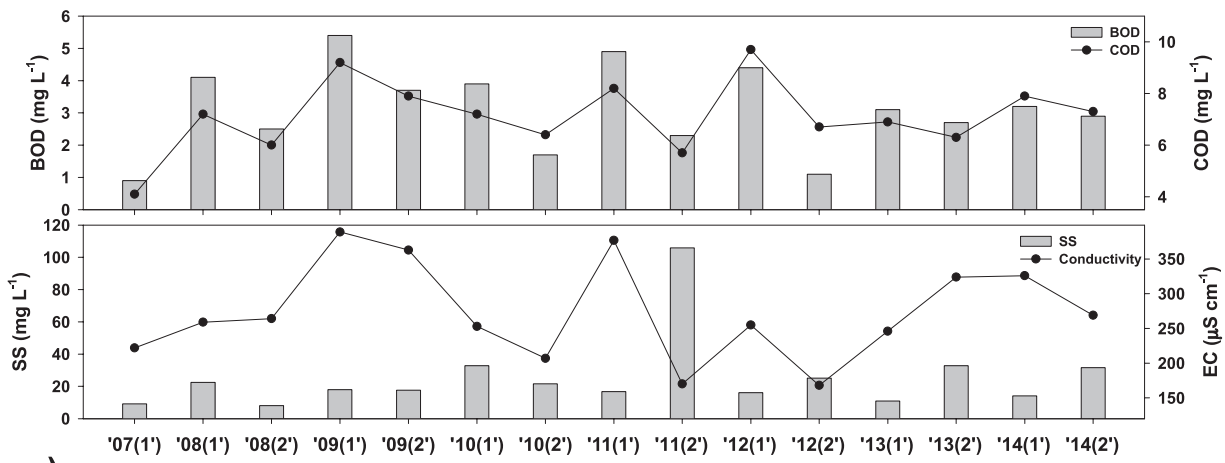

c)

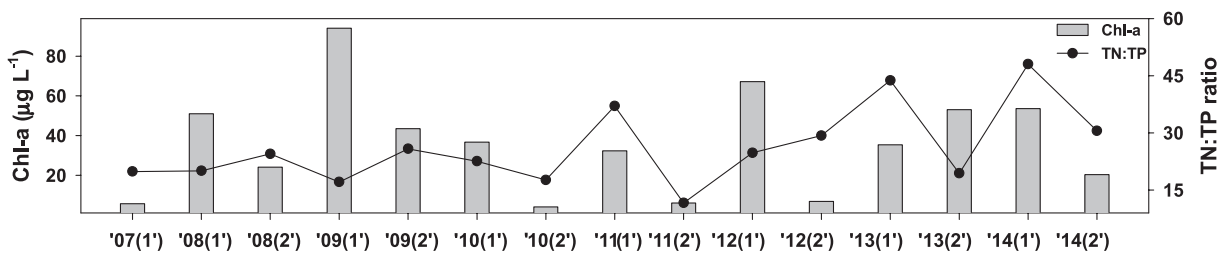

d)

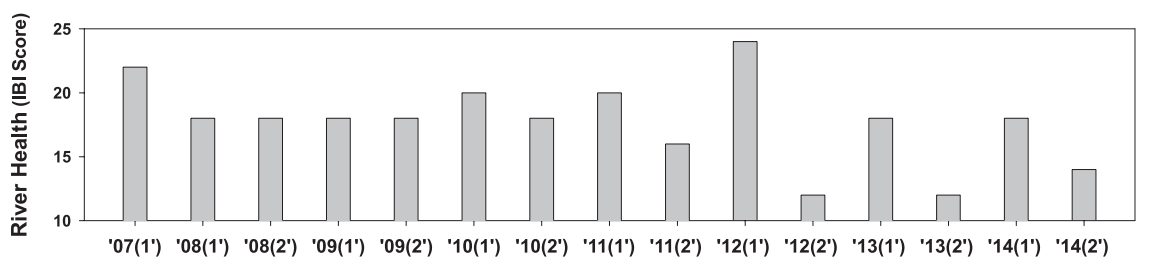

Sampling Year

Fig. 4. Annual fluctuations in: a) nutrient regime, b) organic matter and other parameters, c) chlorophyll-a as a measure of primary production and N:P ratio, and d) biological river health based on the multimetric fish model during 2007-2014. 
the ecosystem health was graded as condition $\mathrm{C}$ to $\mathrm{D}$. Under such fair-to-poor conditions, species composition is generally dominated by low-sensitivity, highly omnivorous, and tolerant species [39, 40]. This trend in species composition and trophic guilds was evident in the present study. In particular, low-IBI values were observed during 2013-2014. Overall, fish habitats were considered to have been disturbed by weir construction. We speculate that ecosystem health degradation is highly associated with habitat conditions and chemical pollution [25, 41], although the flow volume in the stream is another important factor influencing biological health. In the analysis of the metrics, the values of M2 (number of riffle benthic species) and M3 (number of sensitive species) averaged 1.1 and 1.0, respectively, which were particularly low among the metrics. This result indicates that riffle zones, composed mainly of pebbles and gravel, are absent or rare around the Sejong Weir.

\section{Water Chemistry}

As an indicator of organic matter pollution, the mean BOD showed no significant difference $(p>0.05)$ from $\mathrm{B}_{\mathrm{wc}}\left(2.53 \mathrm{mg} \mathrm{L}^{-1}\right.$, range: $\left.0.9-4.5 \mathrm{mg} \mathrm{L}^{-1}\right)$ to $\mathrm{A}_{\mathrm{wc}}$
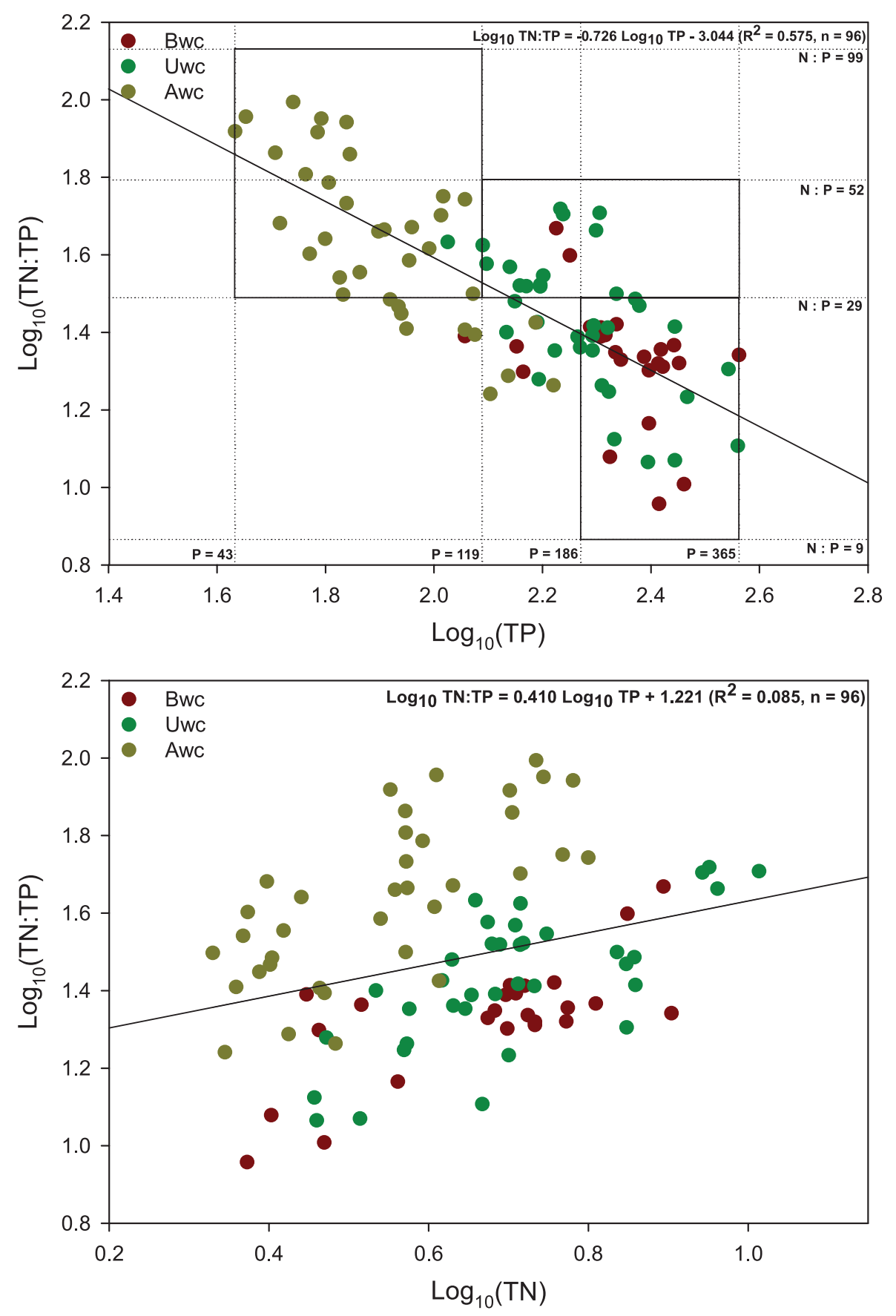

Fig. 5. Relationships between the log-transformed total nitrogen to total phosphorus (TN:TP) ratio and log-transformed TP and TN before $\left(\mathrm{B}_{\mathrm{wc}}\right)$, during $\left(\mathrm{U}_{\mathrm{wc}}\right)$, and after $\left(\mathrm{A}_{\mathrm{wc}}\right)$ weir construction. 
(2.50 mg L $\mathrm{m}^{-1}$, range: $1.0-4.5 \mathrm{mg} \mathrm{L}^{-1}$; Fig. 3). EC showed a similar trend of 312.0 (range: $110-453 \mu \mathrm{S}$ ) $\mathrm{cm}^{-1} \mathrm{~B}_{\mathrm{wc}}$ versus 324 (range: 168-504) $\mu \mathrm{S} \mathrm{cm}^{-1} \mathrm{~A}_{\mathrm{wc}}$ (Fig. 3). As an indicator of eutrophication or nutrient enrichment, the mean TP concentration decreased substantially from 226 (range: 114-365) $\mu \mathrm{g} \mathrm{L}^{-1} \mathrm{~B}_{\mathrm{wc}}$ to 85.3 (range: 43-116) $\mu \mathrm{g} \mathrm{L}^{-1} \mathrm{~A}_{\mathrm{wc}}$ (Fig. 3). The significant reduction in the mean TP was attributed mainly to sedimentation of particulate $\mathrm{P}$ due to the shift from a lotic to lentic waterbody [42]. Trophic state was determined based on the criteria of eutrophication established by the OECD [43], and both the $\mathrm{B}_{\mathrm{wc}}$ and $\mathrm{A}_{\mathrm{wc}}$ systems were categorized as hypereutrophic to eutrophic. DTP showed a similar trend as that of TP (Fig. 3). P is a key limiting factor that regulates algal growth in lentic ecosystems. The mean Chl-a level showed a similar pattern $\mathrm{A}_{\mathrm{wc}}$ (mean: $\left.28 \mu \mathrm{g} \mathrm{L}^{-1}\right)$ in response to $\mathrm{TP}$, and the mean Chl-a $\mathrm{A}_{\mathrm{wc}}$

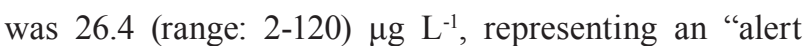
condition" in algal severity based on the Ministry of the Environment of Korea guidelines (Fig. 3). Meanwhile, long-term fluctuations in nutrient regimes were evident. The TN and TP concentrations decreased substantially (Fig. 4), and the N:P ratio increased, $\mathrm{A}_{\mathrm{wc}}$. Overall, these parameters indicated a worsening of biological river health after construction of the Sejong Weir (Fig. 4). By contrast, organic matter, measured as BOD and chemical oxygen demand, differed little between the two periods.

\section{Relationship between the N:P Ratio and Nutrients}

The annual mass ratio of TN:TP averaged 34.7 (range: 9.1 to 98.6 ) (Fig. 5), and variations due to

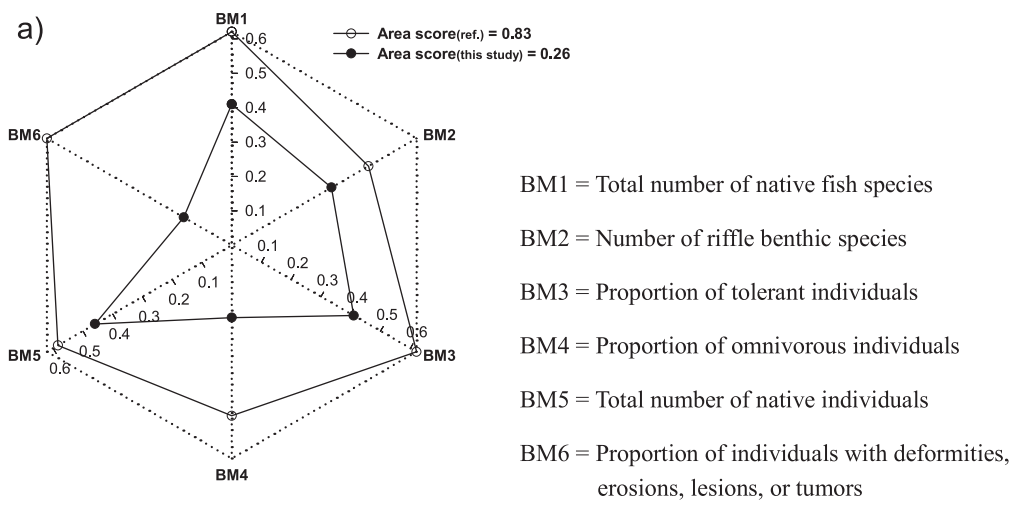

b)

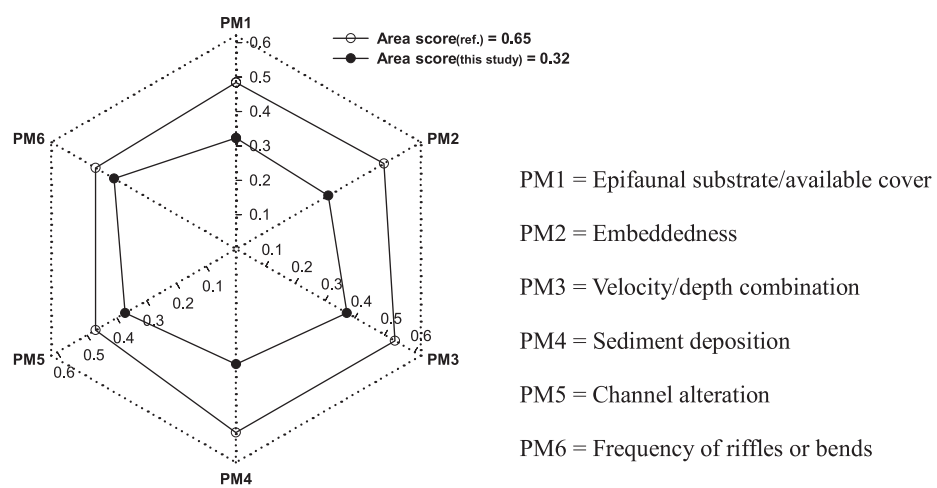

c)

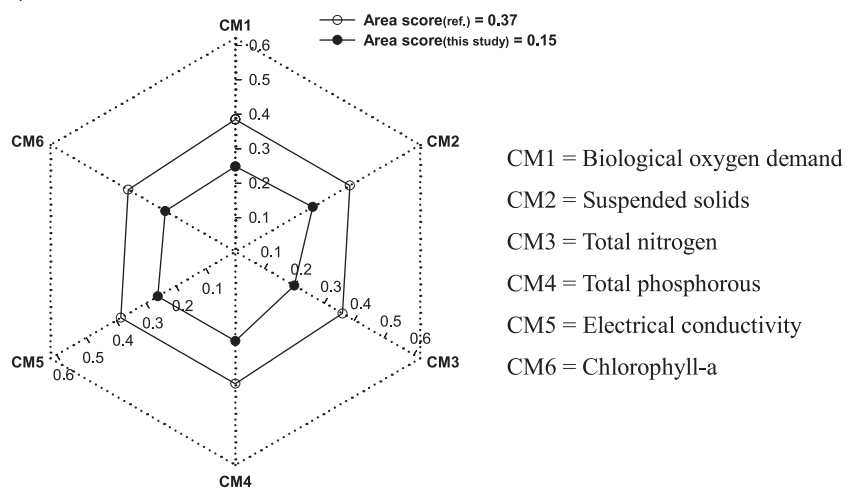

Fig. 6. Integrated a) ecological health assessments of biological (index of biological integrity), b) physical (qualitative habitat evaluation index), and c) chemical (water quality) health at the sampling site in relation to the reference site. 
weir construction were evident. The mean ratios $\mathrm{B}_{\mathrm{wc}}$, $\mathrm{U}_{w c}$, and $\mathrm{A}_{\mathrm{wc}}$ were 22.6, 28.8, and 48.6, respectively. Forsberg [44] suggested that the effects of $\mathrm{N}$ limitation on phytoplankton growth occur at TN:TP ratios $<10$, whereas $\mathrm{P}$ limitation is common at TN:TP ratios $>17$. During the study, $91.7 \%$ of the total TN:TP ratio observations $(\mathrm{n}=96)$ were $>17$ (Fig. 4$)$, and $1 \%(\mathrm{n}=1)$ was $<10$. This suggested that $\mathrm{P}$ was a potential limiting factor of algal growth in the reservoir, and the degree of $\mathrm{P}$ limitation varied seasonally, which is common in Korean reservoirs. This is because seasonal rainfall fluctuates very much according to the Asian monsoon. The $\log _{10}(\mathrm{TP})$ values $\mathrm{B}_{\mathrm{wc}}$ were generally $>2.1$, whereas most $A_{w c}$ values were $<2.1$, showing distinct differences in TP. In addition, the mean $\log _{10}$ (TN:TP) differed significantly $(p<0.05) \mathrm{B}_{\mathrm{wc}}$ (dark brown, Fig. 4) and $\mathrm{A}_{\mathrm{wc}}$ (pale yellow, Fig. 4). Thus, the $\log _{10}(\mathrm{TP})$ and $\log _{10}(\mathrm{~N}: \mathrm{P})$ values showed distinct differences between the two periods, indicating a change in the nutrient regime due to weir construction. Empirical analysis of trophic variables (Fig. 5) showed that $\log _{10}$ (TN:TP) had a weak positive correlation $\left(p<0.005, \mathrm{R}^{2}=0.085, \mathrm{n}=96\right)$ with TN and a strong negative correlation $(p<0.001$, $\left.\mathrm{R}^{2}=0.575, \mathrm{n}=96\right)$ with TP. This indicated that the $\mathrm{N}: \mathrm{P}$ ratio was mainly regulated by variations in TP rather than TN (Fig. 5). The weaker correlation between the $\mathrm{N}: \mathrm{P}$ ratio and $\mathrm{N}$ was probably attributed to the richness and lower variability in $\mathrm{N}$ relative to $\mathrm{P}$ in this system.

\section{Integrated Ecological Health Assessments Based on Physical, Chemical, and Biological Metric Parameters}

An integrated ecological health model based on the star plot approach was used to diagnose the overall ecological river health. The mean model values of integrated health were derived by integrating biological health using the IBI, physical habitat health using the qualitative habitat evaluation index, and chemical health using the nutrient pollution index. The area score of biological health in this study was 0.26 , which was three times lower than that of the reference site $(0.83)$ (Fig. 6). The difference was predominantly because the proportions of abnormal individuals and omnivorous species at the sample sites were significantly greater $(p<0.05)$ than those at the reference site; the values of the axis of abnormal individuals and omnivorous species at the sampling site were 0.16 and 0.21 , respectively. Regarding physical habitat health, all six values of the axis were $\geq 0.31$, representing the largest area score compared with the chemical health and biological health scores, but the mean area score $(0.32)$ was still approximately half that of the reference site (0.65). Chemical water quality health had the lowest mean area score (0.15), and the axis values of all parameters were similarly low, indicative of a substantial degradation of chemical water quality health.

\section{Acknowledgements}

This research was supported by Daejeon Green Environment Center under the Research Developmnet Program (Yr. 2018).

\section{Conflict of Interest}

All the authors declare no conflict of interest.

\section{References}

1. AHN J.M., LEE S., KANG T. Evaluation of dams and weirs operating for water resource management of the Geum River. Science of the Total Environment, 478, 103, 2014.

2. CHOI I.C., SHIN H.J., NGUYEN T.T., TENHUNEN J. Water policy reforms in South Korea: A historical review and ongoing challenges for sustainable water governance and management. Water, 9 (9), 717. 2017.

3. LAH T.J., PARK Y., CHO Y.J. The four major rivers restoration project of South Korea: an assessment of its process, program, and political dimensions. The Journal of Environment \& Development, 24 (4), 375, 2015.

4. HAN H. Authoritarian environmentalism under democracy: Korea's river restoration project. Environmental Politics, 24 (5), 810, 2015.

5. PARK Y., PYO J., KWON Y.S., CHA Y., LEE H., KANG T., CHO K.H. Evaluating physico-chemical influences on cyanobacterial blooms using hyperspectral images in inland water, Korea. Water Research, 126, 319, 2017.

6. BAEK K.O., KU Y.H., KIM Y.D. Attraction efficiency in natural-like fishways according to weir operation and bed change in Nakdong River, Korea. Ecological Engineering, 84, 569, 2015.

7. MOON S.D., HAN J.H., AN K.G. Fish species compositions and the application of ecological assessment models to Bekjae weir, Keum-River watershed. Journal of Environmental Science International, 24 (6), 731,. 2015.

8. YU J.J., LEE K.L., LEE H.J., HWANG J.W., LYU H.S., SHIN L.Y., CHEN S.U. Relations of nutrient concentrations on the seasonality of algal community in the Nakdong River, Korea. Journal of Korean Society on Water Environment, 31 (2), 110, 2015.

9. PARK Y., PYO J., KWON Y.S., CHA Y., LEE H., KANG T., CHO K.H. Evaluating physico-chemical influences on cyanobacterial blooms using hyperspectral images in inland water, Korea. Water Research, 126, 319, 2017.

10. JEONG A., JUNG K. Analysis of long-term riverbed-level and flood stage variation due to water gate operation of multi-functional weirs at Geum River. Journal of Korea Water Resources Association, 48 (5), 379, 2015.

11. KANG N., AN K.G. Statoblast ultrastructure and genetic identity of Pectinatella magnifica population, based on COI gene, from three different watersheds in Korea. Animal Cells and Systems, 19 (1), 78, 2015.

12. CALDERON M.S., AN K.G. An influence of mesohabitat structures (pool, riffle, and run) and land-use pattern on the index of biological integrity in the Geum River watershed. Journal of Ecology and Environment, 40 (1), 13, 2016. 
13. LEE H., KOO M.H., KIM K., KIM Y. Spatio-temporal variations in stream-aquifer interactions following construction of weirs in Korea. Groundwater, 54 (3), 448, 2016.

14. ROLLS R.J., BALDWIN D.S., BOND N.R., LESTER R.E., ROBSON B.J., RYDER D.S., WATSON G.A. A framework for evaluating food-web responses to hydrological manipulations in riverine systems. Journal of Environmental Management, 203, 136, 2017.

15. WARD J.V., STANFORD J.A. Ecological factors controlling stream zoobenthos with emphasis on thermal modification of regulated streams. In: The ecology of regulated streams (pp. 35-55). Springer, Boston, MA. 1979.

16. LANDEMAINE V., GAY A., CERDAN O., SALVADORBLANES S., RODRIGUES S. Morphological evolution of a rural headwater stream after channelisation. Geomorphology, 230, 125, 2015.

17. KWAK S.D., CHOI J.W., AN K.G. Chemical water quality and fish component analyses in the periods of before and after the weir constructions in Yeongsan River. Journal of Ecology and Environment, 39 (1), 99, 2016.

18. BAUMGARTNER L.J., CONALLIN J., WOODEN I., CAMPBELL B., GEE R., ROBINSON W.A., MALLEN-COOPER M. Using flow guilds of freshwater fish in an adaptive management framework to simplify environmental flow delivery for semi-arid riverine systems. Fish and Fisheries, 15 (3), 410, 2014.

19. SHEWIT G., GETAHUN A., ANTENEH W., GEDIF B., GASHU B., TEFERA B., ALEMAW D. Effect of large weirs on abundance and diversity of migratory Labeobarbus species in tributaries of Lake Tana, Ethiopia. African Journal of Aquatic Science, 42 (4), 367, 2017.

20. CHA S.M., KANG M.J., PARK Y., LEE S.W., KIM J.H. Water quality changes according to the midstream weir construction in the Yeongsan River, Korea. Desalination and Water Treatment, 53 (11), 3066, 2015.

21. KO D.G., CHOI J.W., AN K.G. Preliminary ecological assessments of water chemistry, trophic compositions, and the ecosystem health on massive constructions of three weirs in Geum-River watershed. Journal of Ecology and Environment, 39 (1), 61, 2016.

22. KWON H.H., HAN J.H., YOON J., AN K.G. Influence of fish compositions and trophic/tolerance guilds on the fish-kills in Geum-River watershed (Backje Weir). Korean Journal of Environmental Biology 31, 393,. 2013.

23. OHIO E.P.A. Biological criteria for the protection of aquatic life. volume III: standardized biological field sampling and laboratory methods for assessing fish and macroinvertebrate communities. Ohio Environmental Protection Agency, Columbus, Ohio. 1989.

24. AN K.G., KIM D.S., KONG D.S., KIM S.D. Integrative assessments of a temperate stream based on a multimetric determination of biological integrity, physical habitat evaluations, and toxicity tests. Bulletin of Environmental Contamination and Toxicology, 73 (3), 471, 2004.

25. AN K.G., PARK S.S., SHIN J.Y. An evaluation of a river health using the index of biological integrity along with relations to chemical and habitat conditions. Environment International, 28 (5), 411, 2002.

26. KLEMM D.J., STOBER Q.J., LAZORCHAK J.M. Fish field and laboratory methods for evaluating the biological integrity of surface waters (EPA/600/R-92/111). US Environmental Protection Agency, Cincinnati, Ohio. 1993.
27. BARBOUR M.T., GERRITSEN J., SNYDER B.D., STRIBLING J.B. Rapid bioassessment protocols for use in streams and wadeable rivers: periphyton, benthic macroinvertebrates and fish (Vol. 339). US Environmental Protection Agency, Office of Water, Washington, DC. 1999.

28. GIBSON G.R., BARBOUR M.T., STRIBLING J.B., GERRITSEN J., KARR J.R. Biological criteria: Technical guidance for streams and small rivers (No. PB-96-209770/ XAB; EPA-822/B-96/001). US Environmental Protection Agency, Office of Water, Washington DC. 1996.

29. BELIAEFF B., BURGEOT T. Integrated biomarker response: a useful tool for ecological risk assessment. Environmental Toxicology and Chemistry, 21 (6), 1316, 2002.

30. KIM J.H., YEOM D.H., AN K.G. Diagnosis of Sapkyo Stream watershed using the approach of integrative starplot area. Korean Journal of Ecology and Environment, 43, 356, 2010.

31. LEE J.H., KIL J.T., JEONG S. Evaluation of physical fish habitat quality enhancement designs in urban streams using a 2D hydrodynamic model. Ecological Engineering, 36 (10), 1251, 2010.

32. IM D., KANG H., KIM K.H., CHOI S.U. Changes of river morphology and physical fish habitat following weir removal. Ecological Engineering, 37 (6), 883,. 2011.

33. KIM J.H., YOON J.D., HEO W.M., KIM D.S., KIM C., JANG M.H. Movement patterns of three freshwater fish species after upstream transportation by fishway in the Jangheung Dam. Paddy and water environment, 12 (1), 141, 2014.

34. KIM J.Y., AN K.G. Integrated ecological river health assessments, based on water chemistry, physical habitat quality and biological integrity. Water, 7 (11), 6378, 2015.

35. AN K.G., HONG Y.P., KIM J.K., CHOI S.S. Studies on zonation and community analysis of freshwater fish in Kum-river. Korean Journal of Limnology, 25, 99, 1992.

36. KIM H.M., KIL J.H., LEE E.H., AN K.G. Distribution characteristics of largemouth bass (Micropterus salmoides) as an exotic species, in some medium-to-large size Korean reservoirs and physico-chemical water quality in the habitats. Korean Journal of Ecology and Environment, 46, 2013.

37. JANG M.H., JOO G.J., LUCAS M.C. Diet of introduced largemouth bass in Korean rivers and potential interactions with native fishes. Ecology of Freshwater Fish. 15 (3), 315, 2006.

38. JANG M.H., KIM J.G., PARK S.B., JEONG K.S., CHO G.I., JOO G.J. The current status of the distribution of introduced fish in large river systems of South Korea. International Review of Hydrobiology, 87 (2-3), 319, 2002.

39. HAN J.H., PAEK W.K., AN K.G. Water Quality Characteristics and Fish Community of the Gucheon Reservoir and Yeoncho Reservoir in Geoge Island. Korean Journal of Environment and Ecology, 29 (1), 29, 2015.

40. LEE J.H., AN K.G. Integrative restoration assessment of an urban stream using multiple modeling approaches with physical, chemical, and biological integrity indicators. Ecological engineering, 62, 153, 2014.

41. LIU J., LIU Q., YANG H. Assessing water scarcity by simultaneously considering environmental flow requirements, water quantity, and water quality. Ecological indicators, 60, 434, 2016. 
42. MAMUN M., AN K.G. Major nutrients and chlorophyll dynamics in Korean agricultural reservoirs along with an analysis of trophic state index deviation. Journal of AsiaPacific Biodiversity, 10 (2), 183, 2017.

43. ORGANISATION FOR ECONOMIC CO-OPERATION AND DEVELOPMENT. Eutrophication of waters: monitoring, assessment and control. Organisation for
Economic Co-operation and Development, Washington, DC [Sold by OECD Publications and Information Center]. 1982.

44. FORSBERG C. Eutrophication parameters and trophic state indices in 30 Swedish waste-receiving lakes. Archiv fur Hydrobiologia, 89, 189, 1980. 